\title{
An Epoxygenase Metabolite of Arachidonic Acid Mediates Angiotensin II-induced Rises in Cytosolic Calcium in Rabbit Proximal Tubule Epithelial Cells
}

\author{
Zuhayr T. Madhun, David A. Goldthwait, Deborah McKay, Ulrich Hopfer, and Janice G. Douglas \\ Division of Endocrinology and Hypertension, Department of Medicine, University Hospitals of Cleveland, and Department of Physiology \\ and Biophysics, Case Western Reserve University School of Medicine, Cleveland, Ohio 44106
}

\begin{abstract}
Previous studies from this and other laboratories have shown that angiotensin II (AII) induces $\left[\mathrm{Ca}^{2+}\right]_{1}$ transients in proximal tubular epithelium independent of phospholipase C. AII also stimulates formation of 5,6-epoxyeicosatrienoic acid $(5,6$ EET) from arachidonic acid by a cytochrome $\mathbf{P 4 5 0}$ epoxygenase and decreases $\mathrm{Na}^{+}$transport in the same concentration range. Because 5,6-EET mimics AII with regard to $\mathrm{Na}^{+}$transport, its effects on calcium mobilization were evaluated. $\left[\mathrm{Ca}^{2+}\right]_{i}$ was measured by video microscopy with the fluorescent indicator fura-2 employing cultured rabbit proximal tubule. AII-induced $\left[\mathrm{Ca}^{2+}\right]_{\mathrm{i}}$ transients were enhanced by arachidonic acid and attenuated by ketoconazole, an inhibitor of cytochrome P450 epoxygenases. Arachidonic acid also elicited a $\left[\mathrm{Ca}^{2+}\right]_{\text {t }}$ transient that was attenuated by ketoconazole. 5,6-EET augmented $\left[\mathrm{Ca}^{2+}\right]_{\mathrm{i}}$ similar to that seen with AII, but was unaffected by ketoconazole. By contrast, the other regioisomers $(8,9-, 11,12-$, and $14,15-E E T)$ were much less potent. $\left[\mathrm{Ca}^{2+}\right]_{\mathrm{i}}$ transients resulted from influx through verapamil- and nifedipine-sensitive channels. These results suggest a novel mechanism for AII-induced $\mathrm{Ca}$ mobilization in proximal tubule involving cytochrome P450-dependent arachidonic acid metabolism and $\mathrm{Ca}$ influx through voltage-sensitive channels. (J. Clin. Invest. 1991. 88:456-461.) Key words: eicosanoids - voltage-sensitive calcium channels • fura-2 • ketoconazole • cytochrome P450
\end{abstract}

\section{Introduction}

A number of studies have been concerned with the signaling mechanisms coupled to angiotensin II (AII) ${ }^{1}$ receptors and demonstrated several different transduction pathways, depending on the type of cell, including phospholipase C (PLC),

Portions of this worked were presented at the Annual Meeting of the American Federation of Clinical Research (Washington, DC, 4-7 May 1990) and published in abstract form (1990. Clin. Res. 38:314A).

Address reprint requests to Janice G. Douglas, M.D., Dept. of Medicine, Division of Endocrinology and Hypertension, Case Western Reserve University, School of Medicine, Room W165C, 2040 Adelbert Road, Cleveland, OH 44106.

Received for publication 4 October 1990 and in revised form 1 April 1991.

1. Abbreviations used in this paper: AII, angiotensin II; 5,6-EET, 5,6epoxyeicosatrienoic acid; 5-HETE, 5-hydroxyeicosatetraenoic acid; $\mathrm{IP}_{3}$, inositol-tris-phosphate; PLA ${ }_{2}$, phospholipase $\mathrm{A}_{2} ; \mathrm{PLC}$, phospholipase $\mathrm{C}$.

J. Clin. Invest.

(c) The American Society for Clinical Investigation, Inc.

0021-9738/91/08/0456/06 \$2.00

Volume 88, August 1991, 456-461 phospholipase $\mathrm{A}_{2}\left(\mathrm{PLA}_{2}\right)$, adenylate cyclase, and direct regulation of ion channels (1-9). PLC is the predominant pathway in the majority of target tissues, e.g., glomerular mesangium (6), vascular smooth muscle $(7,8)$, and adrenal glomerulosa (9). Activation of PLC results in liberation of diacylglycerol and inositol-tris-phosphate $\left(\mathrm{IP}_{3}\right)$ from phosphatidyl-inositol-4,5bis-phosphate; in turn, $\mathrm{IP}_{3}$ stimulates the release of $\mathrm{Ca}$ from intracellular stores into the cytosol, resulting in a transient increase in cytosolic Ca levels $\left(\left[\mathrm{Ca}^{2+}\right]_{i}\right)$. AII in the concentration range of $10^{-8}$ to $10^{-6} \mathrm{M}$ also increased $\left[\mathrm{Ca}^{2+}\right]_{\mathrm{i}}$ in proximal tubule cells from rabbit kidney, but in these cells the AII-induced $\mathrm{Ca}$ transients could be disassociated from PLC on the basis of two observations (3): First, AII-induced increases in $\left[\mathrm{Ca}^{2+}\right]_{\mathrm{i}}$ were dependent on extracellular $\mathrm{Ca}$; and second, AII failed to stimulate hydrolysis of phosphatidyl-inositol-4,5-bis-phosphate. Therefore, other signaling mechanisms coupling AII to elevation of $\left[\mathrm{Ca}^{2+}\right]_{i}$ need to be considered.

We recently demonstrated that AII stimulates the production of 5,6-epoxyeicosatrienoic acid (5,6-EET) in proximal tubule cells $(10)$, suggesting that 5,6-EET may play a role in the signal transduction of AII regulation. 5,6-EET is a metabolite of arachidonic acid which is produced by a cytochrome $\mathbf{P 4 5 0}$ epoxygenase in an NADPH-dependent manner. This cytochrome P450 epoxide formation represents a third major pathway for metabolism of arachidonic acid, besides the reactions mediated by cyclooxygenase and lipoxygenase (11). It may be the major one in the proximal tubule as this area is deficient in cyclooxygenase and lipoxygenase (12-14). Interestingly, 5,6-EET increased $\left[\mathrm{Ca}^{2+}\right]_{i}$ in pituitary and parotid cells $(15,16)$ and was implicated to mediate secretory responses (17-21). The mechanism whereby $5,6-E E T$ increases $\left[\mathrm{Ca}^{2+}\right]_{\mathrm{i}}$ has not been investigated; other eicosanoids, such as $\mathrm{PGF}_{2 \alpha}$, $\mathrm{PGE}_{2}$, 5-hydroxyeicosatetraenoic acid (5-HETE), and leukotriene $\mathrm{B}_{\mathbf{4}}$, are known to induce rises in $\left[\mathrm{Ca}^{2+}\right]_{i}$ primarily from intracellular stores through $\mathrm{IP}_{3}$-dependent mechanisms and, to a lesser extent, through influx of extracellular $\mathrm{Ca} \mathrm{(22-26).}$

The present study was designed to test the hypothesis that AII-induced increases in $\left[\mathrm{Ca}^{2+}\right]_{i}$ in the proximal tubule arise secondary to release of arachidonic acid and production of 5,6EET. Tissue cultures of rabbit proximal tubule cells provided a convenient experimental system for evaluation of this hypothesis. The results suggest that indeed a novel signaling mechanism involving cytochrome P450 metabolism of arachidonic acid is functional in cells from the proximal tubule.

\section{Methods}

Cell isolation. Renal proximal tubule cells were isolated from male New Zealand White rabbits, ( $2 \mathrm{~kg}$ body $\mathrm{wt}$ ) as previously described ( 3 , 27). Briefly, the method involves homogenization of the renal cortex and separation of fully dissociated cells on a discontinuous $30-60 \%$ Percoll gradient. Cells with a density around $1.026 \mathrm{~g} / \mathrm{ml}$ were removed and cultured on Costar tissue culture flasks according to Chung et al. 
(28). The standard growth medium was a 50:50 mixture of Dulbecco's modified Eagle's (DMEM) and Ham's F12 media supplemented with $15 \mathrm{mM}$ Hepes buffer, $\mathrm{pH} 7.35,1.2 \mathrm{mg} / \mathrm{ml}$ sodium bicarbonate, 192 $\mathrm{IU} / \mathrm{ml}$ penicillin, $200 \mu \mathrm{g} / \mathrm{ml}$ streptomycin, $5 \mu \mathrm{g} / \mathrm{ml}$ bovine insulin, 5 $\mu \mathrm{g} / \mathrm{ml}$ human transferrin, $5 \times 10^{-8} \mathrm{M}$ hydrocortisone, and 5\% FBS. Cells from the $1.026 \mathrm{~g} / \mathrm{ml}$ Percoll fraction had previously been shown to be derived mainly from the proximal tubule $(3,27,29,30)$. Cells were passaged after $2 \mathrm{wk}$, when they usually were in a subconfluent state, by dissociation with trypsin and EDTA and replating on No. 1 glass cover slips. They were used for experiments when isolated colonies were discernible. The media was changed at least 12-24 h before any experiment.

Fura-2 loading. First-passage cells on cover slips were washed twice with BSS and once more with BSS plus $10 \mathrm{mM}$ D-glucose and $0.1 \%$ albumin. BSS contained (in millimolar) $120 \mathrm{NaCl}, 5 \mathrm{KCl}, 1.5 \mathrm{MgCl}_{2}, 1$ $\mathrm{CaCl}_{2}$, and $25 \mathrm{mM}$ Hepes adjusted to $\mathrm{pH} 7.40$ with $\mathrm{NaOH}$. Cells were warmed to $37^{\circ}$ for $10 \mathrm{~min}$ and then incubated with $1.0 \mu \mathrm{M}$ fura-2-acetoxymethyl ester (fura-2-AM) for 20 min to allow entrapment and hydrolysis of the fura-2 ester (fura-2-AM). Finally, extracellular fura-2 and fura-2-AM were removed by washing with BSS and cells were incubated for another $10 \mathrm{~min}$ at $37^{\circ}$. Cells were washed once more with BSS before mounting the cover slip in the perfusion chamber on the stage of an upright light microscope.

$\left[\mathrm{Ca}^{2+}\right]_{i}$ determinations. $\left[\mathrm{Ca}^{2+}\right]$ measurements depend on the different excitation spectra of free fura- 2 and its Ca-complex (31). Cells were illuminated alternately with 340 and $380 \mathrm{~nm}$ light through the epifluorescence optics of the microscope. The excitation light was provided by a 75W xenon lamp in conjunction with metallic interference filters (Omega, Brattleboro, VT). The light emitted from fura-2 was passed through a 510-nm cut-off filter, detected with a model C1966-20H microchannel plate intensifier (Hamamatsu Corp., Middlesex, NJ) in series with a saticon camera (Photonics Microscopy Inc., Oakbrook, IL), and quantitated with a model MVP-AT frame grabber board (Matrox, Quebec, Canada) mounted internally in a host 286 computer. Normalization of the fluorescent signal was achieved by the ratio method (31) implemented with the Image-1/Fl software (Universal Imaging, Media, PA). In this method a ratio is calculated based on the emission intensity after excitation at 340 and $380 \mathrm{~nm}$. This ratio is a function of the $\left[\mathrm{Ca}^{2+}\right]$ and independent of fura-2 concentration or amount in any particular microscope field, provided the fluorescence signal is within the detection limits of the system and appropriate background setting are applied. Usually 16 video frames of fluorescence images were averaged (i.e., $\sim 0.5 \mathrm{~s}$ ) for each excitation wavelength, then the ratio image calculated, and finally stored on a hard disk. Successive ratio images could be stored at a rate of $\sim 1$ every $5 \mathrm{~s}$.

Conversion of the fura- 2 ratio to $\left[\mathrm{Ca}^{2+}\right]_{i}$ was accomplished by a calibration curve which was constructed with free fura- 2 in a solution consisting of (in millimolar) $0.15 \mathrm{KCl}, 10 \mathrm{MOPS} \mathrm{pH} \mathrm{7.4,1} \mathrm{EGTA,} \mathrm{and}$ appropriate amounts of $\mathrm{CaCl}_{2}$ to yield final $\left[\mathrm{Ca}^{2+}\right]$ between 50 and $1,000 \mathrm{nM}$. The total amounts of $\mathrm{CaCl}_{2}$ necessary to give the desired free $\mathrm{Ca}^{2+}$ were calculated with the program by Fabiato (32). Fura-2 concentrations for the calibration curve were adjusted so that the emitted light intensity was appropriate for the particular analogue settings used for experiments with the renal cells. In preliminary experiments, it was shown for our settings that the ratio at a given free $\left[\mathrm{Ca}^{2+}\right]$ was independent of the fura- 2 concentration. Usually, $10 \mu \mathrm{M}$ fura- 2 was employed for the calibration.

Chamber and perfusion. To study hormonally regulated changes in $\left[\mathrm{Ca}^{2+}\right]$ the cover slips with cultured cells were mounted upside-down on a chamber which could be constantly perfused with BSS by gravity feed. The chamber volume was $0.13 \mathrm{ml}$ and the perfusion rate was usually $\sim 1.4 \mathrm{ml}$ per min. Hormones and putative messengers were introduced by switching to a different BSS containing the experimental agent. With the dead space of the tubing, the time for new solutions to reach the cells in the chamber was $\sim 1.5 \mathrm{~min}$. Access of regulatory agents from the medium to cellular receptors was documented by parathyroid hormone (PTH)-induced $\left[\mathrm{Ca}^{2+}\right]_{\mathrm{i}}$ transients. Experiments were carried out at $22^{\circ}$.
Phosphoinositide labeling and extraction. Subconfluent first passaged epithelial cells on 9-- $\mathrm{cm}^{2}$ culture dishes were cultured for 2-3 din serum-free inositol-free DME/Ham's F12 (50:50 mixture) medium, 4 $\mu \mathrm{Ci} / \mathrm{ml}$ of $m y o-\left[2{ }^{3} \mathrm{H}(N)\right]$-inositol $(16.5 \mathrm{Ci} / \mathrm{mmol}$, New England $\mathrm{Nu}-$ clear, Boston, MA) and other media additives as described earlier. Before stimulation with agonists, monolayers were incubated with BSS containing $10 \mathrm{mM} \mathrm{LiCl}$ for $10 \mathrm{~min}$ at $37^{\circ} \mathrm{C}$. Incubations were performed in triplicate and terminated by the addition of $600 \mu \mathrm{lmethanol}$ and $0.04 \mathrm{M} \mathrm{HCl}$. The monolayers were scraped, extracted with chloroform/phytic acid, the upper phase applied to Dowex columns and eluted with 30-500 mM HCl (33).

Statistical analysis. Results are expressed as mean \pm SEM. Statistical significance was calculated by Student's $t$ test for unpaired data, assuming a significance level of $P<0.05$. All cells in a microscope view were counted, whether or not they responded, and for each experimental condition at least three cover slips were analyzed. The data generally refer to between 10 and 35 cells for each condition unless otherwise stated.

Materials. Hepes, purified bovine PTH (residues 1-84), bradykinin, nifedipine, and ketoconazole were obtained from Sigma Chemical Co. (St. Louis, MO). Chromatographically pure arachidonic acid was purchased from Nu-Check-Prep (Elysian, MN). 5,6-EET, 8,9EET, 11,12-EET, and 14,15-EET, and verapamil were bought from Calbiochem-Behring Corp. (La Jolla, CA). The different epoxides were shipped as methyl esters which were hydrolyzed to the free acids by 10 $\mathrm{N} \mathrm{NaOH}$ in $90 \%$ methanol. AII was purchased from United States Biochemical Corp. (Cleveland, OH). Percoll is a product of Pharmacia Fine Chemicals (Piscataway, NJ). DMEM and Ham's F12 medium were obtained from Gibco (Grand Island, NY). Costar tissue culture flasks were from Costar (Cambridge, MA), No. $122 \times 22 \mathrm{~mm}$ glass cover slip from Fisher Scientific Co. (Pittsburgh, PA), and fura-2 and fura-2-AM from Molecular Probes, Inc. (Eugene, OR).

\section{Results}

Baseline Ca concentration. Mean basal $\left[\mathrm{Ca}^{2+}\right]_{\mathrm{i}}$ of rabbit proximal tubule cells was $126 \pm 4$ nM (347 cells from 46 fields). Pretreatment of cells with $3 \mu \mathrm{M}$ arachidonic acid for $3 \mathrm{~h}$ or with $100 \mu \mathrm{M}$ ketoconazole overnight did not significantly change this value ( $129 \pm 6$ and $122 \pm 5 \mathrm{nM}$, respectively). These basal Ca levels remained unchanged for at least $30 \mathrm{~min}$ perfusion in the microscope chamber.

Signal transduction of AII. AII has been shown to transiently increase $\left[\mathrm{Ca}^{2+}\right]_{\mathrm{i}}$ in intact proximal tubules, primary cultures, and dispersed cell suspensions $(1,3,29,30,34,35)$. The minimal effective AII concentration in these preparations was $\sim 10 \mathrm{nM}$. AII elicited a similar increase in $\left[\mathrm{Ca}^{2+}\right]_{\mathrm{i}}$ in cells attached to glass cover slips. Fig. $1 A$ illustrates a typical response during perfusion of epithelial cells with AII. After a lag time of $\sim 90 \mathrm{~s}$ due to the dead space of the perfusion system, $\left[\mathrm{Ca}^{2+}\right]_{\mathrm{i}}$ rose rapidly and then decayed to baseline over the next 10-15 min. Fig. 2 shows the dose-response curve for AII in terms of peak $\left[\mathrm{Ca}^{2+}\right]_{\mathrm{i}}$ above basal levels. The minimal AII concentration for which increases in $\left[\mathrm{Ca}^{2+}\right]_{\mathrm{i}}$ could be detected was $\sim 0.1 \mathrm{nM}$ suggesting that either the microscope setup for detecting fluorescence changes was more sensitive than those of previous studies $(1,3,29,30,34,35)$ or that the attached, cultured cells are intrinsically more responsive to AII.

Because previous studies $(1,3)$ had implicated arachidonic acid metabolites in the signaling transduction for AII, the effect of arachidonic acid supplementation of the culture medium was tested. Cells were incubated for $3 \mathrm{~h}$ in the usual culture medium plus $3 \mu \mathrm{M}$ arachidonic acid and then the changes in $\left[\mathrm{Ca}^{2+}\right]_{\mathrm{i}}$ in response to AII measured. This protocol resulted in a significantly greater response over the entire range of $10^{-9}$ to 

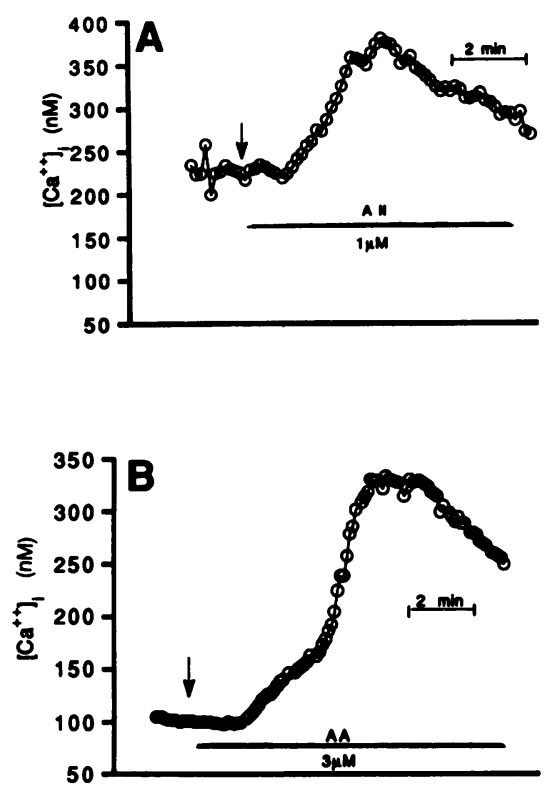
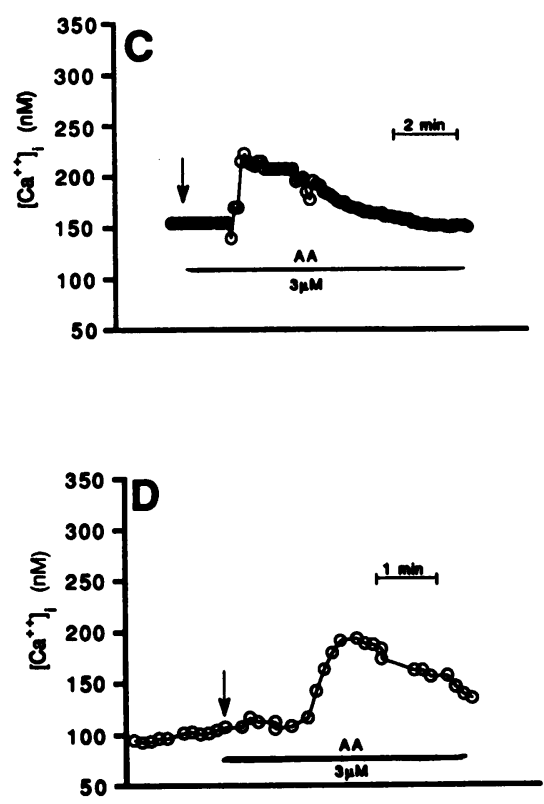

Figure 1. Typical time courses of angiotensin II $(A I I)$ and arachidonate $(A A)$ effects on $\left[\mathrm{Ca}^{2+}\right]_{i}$. $\left[\mathrm{Ca}^{2+}\right]_{i}$ was measured in fura-2loaded cells by video microscopy (see Methods). ( $A$ ) Acute effect of AII; $(B)$ acute effect of AA perfused with BSS, which includes $1 \mathrm{mM} \mathrm{Ca} ;(C)$ cell preincubated with $100 \mu \mathrm{M}$ ketoconazole for $3 \mathrm{~h}$ and perfusion with the same solution as in $B ;(D)$ cell treated as in $B$, but without $\mathrm{Ca}^{2+}$ in the perfusion solution.
$10^{-6} \mathrm{M}$ AII (left shift of dose-response curve) (Fig. 2, upper trace). For example, $1 \mu \mathrm{M}$ AII increased $\left[\mathrm{Ca}^{2+}\right]_{\mathrm{i}}$ in cells grown in basic medium by $230 \mathrm{nM}$, whereas the same concentration of AIl induced a rise in $\left[\mathrm{Ca}^{2+}\right]_{\mathrm{i}}$ by $322 \mathrm{nM}$ in arachidonic acidsupplemented cells $(P<0.05)$.

Involvement of an arachidonic acid metabolite in the signaling pathway is also suggested by the results with ketoconazole, an inhibitor of cytochrome P450 epoxygenases. Preincubation of cells in media supplemented with $100 \mu \mathrm{M}$ ketoconazole greatly inhibited the increases of $\left[\mathrm{Ca}^{2+}\right]_{i}$ in response to AII. This inhibition was present regardless whether the medium contained ketoconazole alone or ketoconazole plus arachidonic acid (Fig. 2, lower trace). By contrast, ketoconazole failed to abolish bradykin-induced $\left[\mathrm{Ca}^{2+}\right]_{\mathrm{i}}$ transients, an effect mediated by activation of phosphoinositide specific phospholipase $\mathrm{C}$.

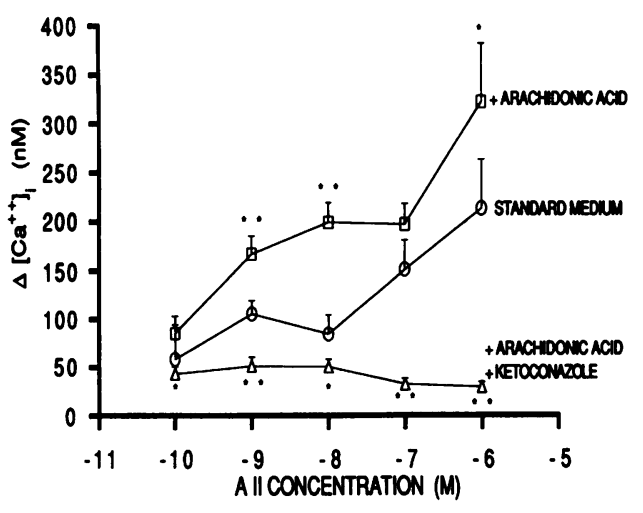

Figure 2. Dose-response relationship of angiotensin II $(A I I)$ and $\left[\mathrm{Ca}^{2+}\right]_{i} .\left[\mathrm{Ca}^{2+}\right]_{i}$ was measured first in the absence and then in presence of AII in the perfusion medium at the indicated concentrations. Peak $\left[\mathrm{Ca}^{2+}\right]_{i}$ minus basal $\left[\mathrm{Ca}^{2+}\right]_{i}$ was averaged for cells incubated in standard medium (circles); cells incubated in standard medium plus $3 \mu \mathrm{M}$ arachidonate for $3 \mathrm{~h}$ (squares); cells incubated in standard medium plus $100 \mu \mathrm{M}$ ketoconazole and $3 \mu \mathrm{M}$ arachidonate for $3 \mathrm{~h}$. Data are given as mean \pm SEM. ${ }^{*} P<0.05,{ }^{* *} P<0.005$, relative to cells grown in standard medium alone at the same AII concentration.
Under basal conditions, bradykinin induced $\left[\mathrm{Ca}^{2+}\right]_{\mathrm{i}}$ of $189 \pm 28$ $\mathrm{nM}(n=14)$ in contrast to $195 \pm 21 \mathrm{nM}(n=18$, NS) after ketoconazole pretreatment.

Interestingly, acute exposure of cells to arachidonic acid brought about an elevation of $\left[\mathrm{Ca}^{2+}\right]_{\mathrm{i}}$ (Fig. $1 \mathrm{~B}$ ). Peak changes in $\left[\mathrm{Ca}^{2+}\right]_{\mathrm{i}}$ for $3 \mu \mathrm{M}$ arachidonic acid were $371 \pm 55 \mathrm{nM}(n=35)$. This response was actually greater than the peak response to AII and was also largely inhibited by pretreatment of cells with ketoconazole (Fig. $1 C$ ). For example, after ketoconazole pretreatment the peak $\mathrm{Ca}$ changes elicited by arachidonic acid decreased to $79 \pm 7 \mathrm{nM}(n=48)$. These results suggested that arachidonic acid and one or more of its epoxygenase metabolites were involved in modulating $\left[\mathrm{Ca}^{2+}\right]_{i}$.

Regioisomers of EET. To evaluate the involvement of 5,6EET in the signaling pathway for $\left[\mathrm{Ca}^{2+}\right]_{i}$, the effect of acute addition of 5,6-EET on $[\mathrm{Ca}]_{i}$ was measured. Fig. 3 illustrates the dose-dependent increases of $\left[\mathrm{Ca}^{2+}\right]_{i}$ that were observed in the range of $10 \mathrm{nM}$ to $1 \mu \mathrm{M} 5,6-\mathrm{EET}$. At $1 \mu \mathrm{M}$, the peak increment of $\left[\mathrm{Ca}^{2+}\right]_{\mathrm{i}}$ was $100 \pm 14 \mathrm{nM}$. Concentrations of 5,6-EET higher than $1 \mu \mathrm{M}$ could not be used because of cellular toxicity. Of interest is the fact that the percentage of cells responding increased from 40 to $100 \%$ over the dose range employed herein. Pretreatment of the cells with $100 \mu \mathrm{M}$ ketoconazole to abolish endogenous EET production potentiated the response of acute additions of 5,6-EET (data not shown). In ketoconazole pretreated cells, $1 \mu \mathrm{M} 5,6-E E T$ produced a $\left[\mathrm{Ca}^{2+}\right]_{\mathrm{i}}$ increase of $168 \pm 14 \mathrm{nM}$, which was significantly $(P<0.005)$ higher than the $100 \mathrm{nM}$ for cells without the inhibitor (see above).

Specificity of the epoxide effect was evaluated by comparing the efficacy of different regioisomers. They were tested at 1 $\mu \mathrm{M}$ with the following results (Table I): 8,9- and 14,15-EET were about one fourth as potent as 5,6-EET, whereas the 11,12 isomer did not elicit any response in the proximal tubule cells. Thus, 5,6-EET was by far the most potent of the four different regioisomers tested.

Source of increases in $\left[\mathrm{Ca}^{2+}\right]_{i} \cdot\left[\mathrm{Ca}^{2+}\right]_{\mathrm{i}}$ can be elevated by influx of $\mathrm{Ca}^{2+}$ either from intracellular stores or from the extracellular medium. To evaluate the contribution of $\mathrm{Ca}$ from the extracellular medium, $\left[\mathrm{Ca}^{2+}\right]_{\mathrm{i}}$ levels were measured in response 


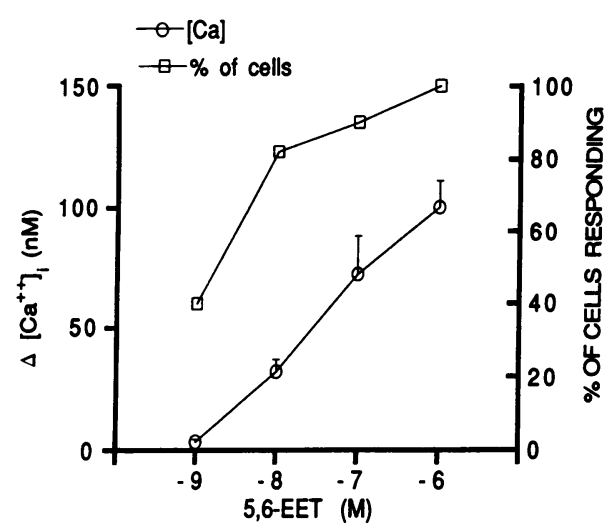

Figure 3. Effects of 5,6-epoxyeicosatrienoic acid (5,6-EET) on $\left[\mathrm{Ca}^{2+}\right]_{\mathbf{i}}$. $\left[\mathrm{Ca}^{2+}\right]_{i}$ was measured first in the absence and then in presence of 5,6EET in the perfusion medium at the indicated concentration (for method see Fig. 1). 5,6-EET was added to the perfusion solution from a $\geq 10 \mathrm{mM}$ stock in $90 \%$ methanol- $10 \mathrm{~N} \mathrm{NaOH}$. The results were analyzed in terms of number of cells responding and average (peak minus basal) $\left[\mathrm{Ca}^{2+}\right]_{i}$. Data are given as mean \pm SEM of 24-36 cells. Note that the number of cells responding and the average peak $\left[\mathrm{Ca}^{2+}\right]_{\mathrm{i}}$ increased with higher 5,6-EET concentrations. Controls with identical amounts of $90 \%$ methanol-10 N NaOH solution, but without epoxide, did not increase $\left[\mathrm{Ca}^{2+}\right]_{i}$.

to AII and putative intermediates when either no extracellular $\mathrm{Ca}$ was present or $50 \mu \mathrm{M} \mathrm{LaCl}_{3}$ in the medium blocked influx across the plasma membrane. Under both conditions, even maximal doses of $1 \mu \mathrm{M} 5,6-E E T$ did not increase $\left[\mathrm{Ca}^{2+}\right]_{i}$, indicating that the 5,6-EET effect depends on influx of extracellular Ca. Similarly, the effects of $3 \mu \mathbf{M}$ arachidonic acid were attenuated, however, only by about two-thirds: $\left[\mathrm{Ca}^{2+}\right]_{i}$ increments of $371 \mathrm{nM}$ in the presence of extracellular Ca dropped to $128 \pm 36 \mathrm{nM}(n=28, P<0.005)$ in Ca-free buffer (Fig. $1 D)$ and to $149 \pm 22 \mathrm{nM}(n=19, P<0.01)$ in the presence of $50 \mu \mathrm{M}$ $\mathrm{LaCl}_{3}$ (data not shown).

It is possible that the residual increase of $\left[\mathrm{Ca}^{2+}\right]_{\mathrm{i}}$ in response to arachidonic acid may have been due to stimulation of phosphoinositide-specific phospholipase $\mathrm{C}$ and release of $\mathrm{Ca}^{2+}$ from intracellular stores. To evaluate this possibility, bradykinin, a known stimulator of phospholipase $\mathrm{C}$, was compared to arachidonic acid, employing myo-inositol labeled epithelial cells. We observed no stimulation of IP, $\mathrm{IP}_{2}$, or $\mathrm{IP}_{3}$ with 0.1 or $1 \mu \mathrm{M}$ arachidonic acid despite brisk stimulation of all three isomers with bradykinin (Table II).

Because voltage-sensitive $\mathrm{Ca}$ channels provide one of the influx pathways in other tissues, their participation was probed

Table I. Effects of EET Regioisomers on $\left[\mathrm{Ca}^{2+}\right]_{i}$

\begin{tabular}{ccc}
\hline Isomer & Peak $\Delta\left[\mathrm{Ca}^{2+}\right]_{\mathrm{i}}$ & No. cells \\
\hline$n M$ & \\
$5,6-\mathrm{EET}$ & $100 \pm 10$ & 36 \\
$8,9-\mathrm{EET}$ & $23 \pm 6$ & 20 \\
$11,12-\mathrm{EET}$ & 0 & 36 \\
$14,15-\mathrm{EET}$ & $27 \pm 5$ & 30
\end{tabular}

All EET isomers were tested at $1 \mu \mathrm{M}$.
Table II. Effects of Arachidonic Acid and Bradykinin on Phosphoinositide-specific Phospholipase C Presented as ${ }^{3} \mathrm{H}$ Inositol Phosphate Accumulation

\begin{tabular}{|c|c|c|c|c|}
\hline & Basal & $\begin{array}{c}\text { Arachidonic } \\
\text { acid } \\
(0.1 \mu \mathrm{M})\end{array}$ & $\begin{array}{c}\text { Arachidonic } \\
\text { acid } \\
(1 \mu \mathrm{M})\end{array}$ & $\begin{array}{c}\text { Bradykinin } \\
(1 \mu \mathrm{M})\end{array}$ \\
\hline \multicolumn{5}{|l|}{$30 \mathrm{~s}$} \\
\hline IP & $\begin{array}{c}1255 \pm 42 \\
(6)\end{array}$ & ND & $\begin{array}{c}1093 \pm 96 \\
(3)\end{array}$ & $\begin{array}{c}5601 \pm 24^{*} \\
\text { (3) }\end{array}$ \\
\hline $\mathrm{IP}_{2}$ & $\begin{array}{c}908 \pm 92 \\
(6)\end{array}$ & ND & $\begin{array}{l}665 \pm 10^{*} \\
\text { (3) }\end{array}$ & $\begin{array}{c}1427 \pm 50^{*} \\
\text { (3) }\end{array}$ \\
\hline $\mathrm{IP}_{3}$ & $\begin{array}{c}722 \pm 46 \\
(6)\end{array}$ & ND & $\begin{array}{c}518 \pm 3 \\
(3)\end{array}$ & $\begin{array}{c}1977 \pm 42^{*} \\
\text { (3) }\end{array}$ \\
\hline \multicolumn{5}{|c|}{$15 \mathrm{~min}$} \\
\hline IP & $\begin{array}{c}1753 \pm 165 \\
(12)\end{array}$ & $\begin{array}{c}930 \pm 70 \\
\text { (3) }\end{array}$ & $\begin{array}{c}1739 \pm 459 \\
(6)\end{array}$ & $\begin{array}{c}7251 \pm 1052^{*} \\
\text { (3) }\end{array}$ \\
\hline $\mathrm{IP}_{2}$ & $\begin{array}{c}1031 \pm 138 \\
(11)\end{array}$ & $\begin{array}{c}484 \pm 37 \\
\text { (3) }\end{array}$ & $\begin{array}{c}737 \pm 166 \\
(6)\end{array}$ & $\begin{array}{c}2168 \pm 78^{*} \\
(3)\end{array}$ \\
\hline $\mathrm{IP}_{3}$ & $\begin{array}{c}617 \pm 51 \\
(12)\end{array}$ & $\begin{array}{c}515 \pm 65 \\
(3)\end{array}$ & $\begin{array}{c}526 \pm 89 \\
(6)\end{array}$ & $\begin{array}{c}1316 \pm 13^{*} \\
(2)\end{array}$ \\
\hline
\end{tabular}

Each value is the mean \pm SE. No. determinations is in parentheses. * Significantly different from basal.

by measuring $\left[\mathrm{Ca}^{2+}\right]_{\mathrm{i}}$ in the presence of the blockers verapamil $(50 \mu \mathrm{M})$ and nifedipine $(10 \mu \mathrm{M})$. Both blockers essentially abolished the responses to AII and 5,6-EET (Fig. 4, $B$ and $C$ ). This inhibition was specific for the plasma membrane since the release of $\mathrm{Ca}$ from $\mathrm{IP}_{3}$-sensitive, intracellular stores by bradykinin $(1 \mu \mathrm{M})$ was not changed by the two blockers (Fig. $4, B$ and $C$ ).

\section{Discussion}

The present study confirms that $0.1 \mathrm{nM}$ to $1 \mu \mathrm{M}$ AII elicits significant rises in cytosolic $\mathrm{Ca}$ in proximal tubule cells. This rise is mediated by arachidonic acid and its metabolites, in particular, 5,6-EET. Three major observations that lead to this conclusion are: First, the epoxygenase inhibitor ketoconazole blocked AII-induced increments in $\left[\mathrm{Ca}^{2+}\right]_{\mathrm{i}}$. Second, the addition of 5,6-EET by itself caused increases in $\left[\mathrm{Ca}^{2+}\right]_{\mathrm{i}}$ similar to those achieved with AII. Third, acute additions of arachidonic acid also resulted in increases in $\left[\mathrm{Ca}^{2+}\right]_{i}$ which could be partially blocked by ketoconazole. The conclusion is also supported by data from other studies in our laboratory indicating that AII does not activate phosphoinositide-specific PLC (3) and that AII stimulates the conversion of arachidonic acid to 5,6 -EET measured by chemical methods $(29,30)$. The involvement of arachidonic acid is also suggested by the enhanced AII response (left shift of dose-response curve) of cells enriched with arachidonic acid by preincubation. Together these results suggest that AII activates either PLA Ar $_{2}$ orospholipase D pathways that lead to the release of arachidonic acid. The arachidonic acid is then metabolized by a specific cytochrome P450 epoxygenase to an epoxide which acts as third messenger in sequence resulting in increased $\mathrm{Ca}$ influx. The most effective epoxide was 5,6-EET.

AII has a biphasic effect on proximal tubular transport wherein $\mathrm{pM}$ concentrations stimulate $\mathrm{Na}$ absorption, whereas 

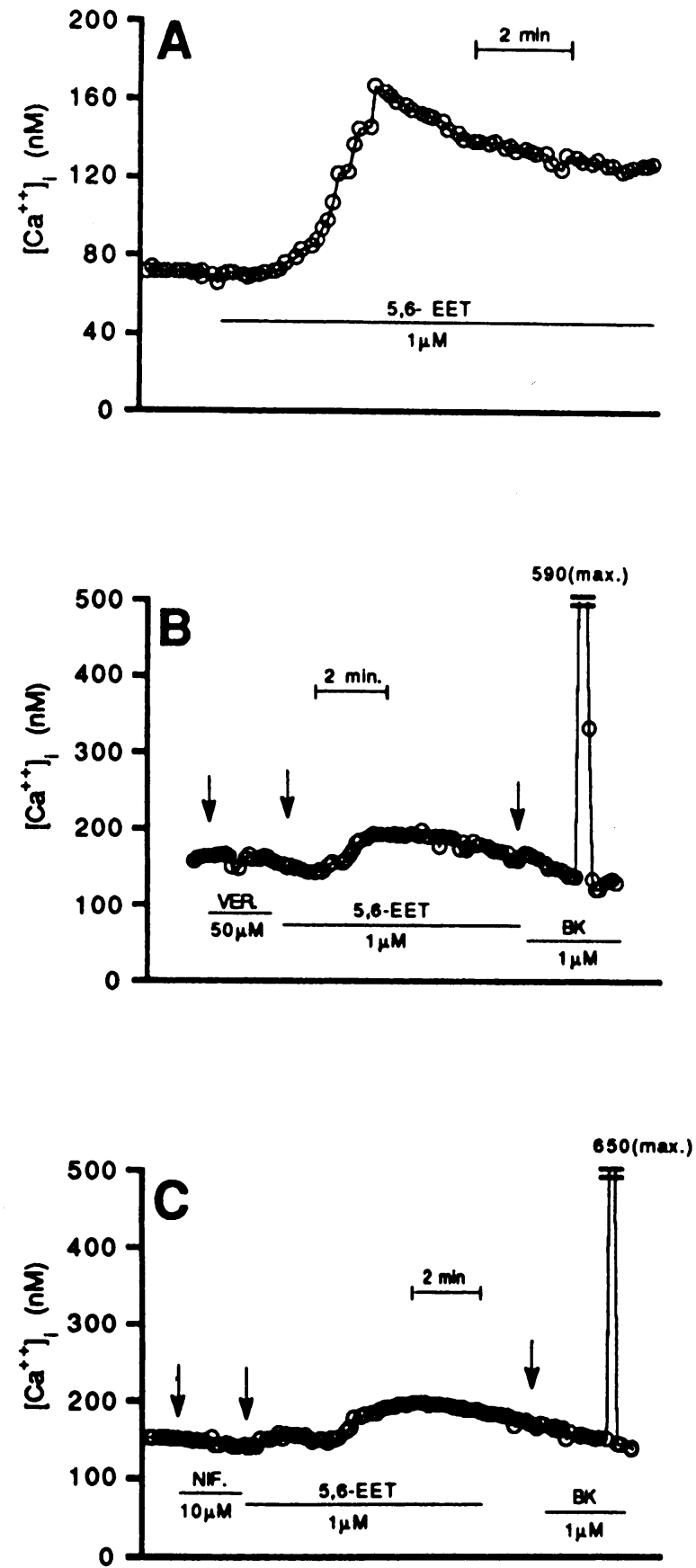

Figure 4. Attenuation of 5,6-EET-induced $\left[\mathrm{Ca}^{2+}\right]_{\mathrm{i}}$ increases by the $\mathrm{Ca}$ channel blockers nifedipine $(N I F)$ and verapamil $(V E R)$. $\left[\mathrm{Ca}^{2+}\right]_{\mathrm{i}}$ was measured as in Fig. 1. Typical cell responses to 5,6-EET are shown $(A)$ and in the presence of $50 \mu \mathrm{M}$ verapamil $(B)$ or $10 \mu \mathrm{M}$ nifedipine $(C)$. Horizontal bars indicate additions to the perfusion medium. Cells were perfused with the blockers for $2 \mathrm{~min}$ as indicated by the horizontal bars and then with $1 \mu \mathrm{M}$ 5,6-EET for an additional $6 \mathrm{~min}$. Subsequently, cells were challenged with $1 \mu \mathrm{M}$ bradykinin $(B K)$ for release of $\mathrm{Ca}$ from intracellular $\mathrm{IP}_{3}$-sensitive stores.

$\mathrm{nM}$ concentrations inhibit $\mathrm{Na}$ absorption $(36,37)$. There is general agreement that AII-induced inhibition in cAMP formation stimulates luminal $\mathrm{Na} / \mathrm{H}$ exchange to facilitate $\mathrm{Na}$ and bicarbonate reabsorption $(1,5,29,30)$, however, much less is known about the signal transduction mechanism that mediates AII-induced natriuresis. There are several reasons to believe that cytochrome P450-dependent arachidonic acid metabolism and consequent effects on $\mathrm{Ca}$ mobilization mediate the inhibitory effect of AII $(5,10,29,30)$. Romero et al. (10, 29, 30, 38) have recently shown in primary cultures of proximal tubule cells that 5,6-EET mimics the inhibitory effect of AII on $\mathrm{Na}$ fluxes from the lumen to the basal compartment. Furthermore, it is likely that these transport effects are mediated by elevation of intracellular $\left[\mathrm{Ca}^{2+}\right]_{\mathrm{i}}$ because ketoconazole inhibits AII-induced $\left[\mathrm{Ca}^{2+}\right]_{\mathrm{i}}$ transients and AII-induced natriuresis (29). Sakhrani et al. (39) demonstrated that when $\left[\mathrm{Ca}^{2+}\right]_{i}$ of proximal tubular cells is increased, either by calcium loading or $\mathrm{Ca}$ ionophore, amiloride-sensitive $\mathrm{Na}$ uptake is inhibited by $25-$ $40 \%$. By contrast, 8 -( $N, N$-diethylamonia)-octyl-3,4,5-trimethoxybenzoate (TMB-8) that prevents intracellular Ca mobilization blocks the inhibitory effect of AII on sodium and bicarbonate transport (40). These observations support the hypothesis that arachidonic acid and cytochrome P450-dependent epoxygenase metabolites mediate the inhibitory effect of AII on sodium and bicarbonate transport through effects on $\mathrm{Ca}$ mobilization. However, the exact mechanism of inhibition by $\left[\mathrm{Ca}^{2+}\right]_{i}$ has not been worked out for the proximal tubule and one report actually suggests that the $\mathrm{Na}^{+} / \mathrm{H}^{+}$exchanger of brush border membranes is not inhibited, but activated by calcium-dependent protein kinases (41).

The observations of this study and those reported earlier $(10,29,30,38)$ indicate that 5,6-EET fulfills the criteria for a second messenger (42): (a) 5,6-EET can be formed by the target tissue, the proximal tubule cells, in response to interaction of AII with its receptor; $(b)$ 5,6-EET specifically elicits an increase in cytosolic $\left[\mathrm{Ca}^{2+}\right]_{i} ;(c)$ AII-induced $\left[\mathrm{Ca}^{2+}\right]_{i}$ transients can be inhibited by compounds that prevent the formation of 5,6 EET (i.e., ketoconazole); (d) 5,6-EET mimics the transport effects of AII. Thus, this novel intracellular epoxide metabolite of arachidonic acid is probably an important modulator of $\left[\mathrm{Ca}^{2+}\right]_{\mathrm{i}}$ in the proximal tubular epithelium which mediates the effect of AII in the concentration range of nanomolar to micromolar.

Formation of 5,6-EET also accounts for the bulk of the effects seen with acute addition of free arachidonic acid. However, with arachidonic acid a substantial residual increase of $\left[\mathrm{Ca}^{2+}\right]_{\mathrm{i}}$ remained even after ketoconazole treatment or after blocking $\mathrm{Ca}$ channels that mediate $\mathrm{Ca}$ influx in response to 5,6-EET. This unaccounted portion may be due to arachidonic acid directly activating $\mathrm{Ca}$ channels analogous to the activation of potassium channels in smooth muscle cells (43). Recent studies from this laboratory demonstrated that arachidonic acid and other unsaturated fatty acids as well as the inhibitor of eicosanoid biosynthesis, eicosatetraynoic acid mobilize $\mathrm{Ca}$ from intracellular stores independent of phosphoinositide-specific phospholipase $C$ (44).

These results indicate that the bulk of the cytosolic $\mathrm{Ca}$ increases in response to AII and its putative intermediates results from $\mathrm{Ca}$ influx into the cell through $\mathrm{Ca}$ transporters that are inhibitable by $\mathrm{Ca}^{2+}$ channel blockers and presumably represent voltage-sensitive $\mathrm{Ca}$ channels. This conclusion agrees with a previous study in proximal tubule cells $(1,3)$ which also pointed to influx of extracellular Ca caused by AII. A similar mechanism appears to be operational in adrenal glomerulosa cells where $\mathrm{Ca}$ channel agonists potentiate AII-induced $\mathrm{Ca}$ influx during the more sustained phase of increased $\left[\mathrm{Ca}^{2+}\right]_{i}(9)$. 


\section{Acknowledgments}

The authors wish to thank Gary Bright, Ph.D., Antonio Scarpa, M.D., Ph.D., and Baha Arafah, M.D. for thoughtful discussion and advice, Jeanette Harris Odenbret and Chris Erhart for expert technical assistance, and Florence Stewart, Janice Carpenter, and Norma Brown for expert secretarial assistance.

These studies were supported by the following National Institutes of Health grants: HL22990, HL39012, HL41618, and DK27651 (J. G. Douglas) and the Rainbow Chapter of the Cystic Fibrosis Foundation.

Note added in proof: Recent more sophisticated chromatographic analyses of the AII-induced metabolites of arachidonic acid suggest that 5,6-EET may not be the major product, but another one that has a similar chromatographic behavior on reverse HPLC.

\section{References}

1. Douglas, J. G. 1987. Angiotensin receptor subtypes of the kidney cortex. Am. J. Physiol. 253:F1-F7.

2. Torres, V. E., T. E. Northrup, R. M. Edwards, S. V. Shah, and T. P. Dousa 1978. Modulation of cyclic nucleotides in isolated rat glomeruli. J. Clin. Invest. 62:1334-1343.

3. Welsh, C., G. Dubyak, and J. G. Douglas. 1988. Relationship between phospholipase $C$ activation and prostaglandin $E_{2}$ and cyclic adenosine monophosphate production in rabbit tubular epithelial cells. J. Clin. Invest. 81:710-719.

4. Woodcock, E. A., and C. I. Johnston. 1982. Inhibition of adenylate cyclase by angiotensin II in rat renal cortex. Endocrinology. 111:1687-1691.

5. Liu, F.-Y., and M. G. Cogan. 1989. Angiotensin II stimulates early proximal bicarbonate absorption in the rat by decreasing cyclic adenosine monophosphate. J. Clin. Invest. 84:83-92.

6. Pfeilschifter, J., and C. Bauer. 1986. Pertussis toxin abolishes angiotensin II-induced phosphoinositide hydrolysis and prostaglandin synthesis in rat renal mesangial cells. Biochem. J. 236:289-294.

7. Smith, J. B., L. Smith, E. R. Brown, D. Barnes, M. A. Sabir, J. S. Davis, and R. V. Farese. 1984. Angiotensin II rapidly increases phosphatidate-phosphoinositide synthesis, phosphoinositide hydrolysis, and calcium mobilization in cultured arterial muscle cells. Proc. Natl. Acad. Sci. USA. 81:7812-7816.

8. Alexander, R. W., T. A. Brock, M. A. Gimbrone, Jr., and S. E. Rittenhouse. 1985. Angiotensin increases inositol triphosphate and calcium in vascula smooth muscle. Hypertension (Dallas). 7:447-451.

9. Hausdorff, W. P., and K. J. Catt. 1988. Activation of dihydropyridine-sensitive calcium channels and biphasic cytosolic calcium responses by angiotensin II in rat adrenal glomerulosa cells. Endocrinology. 123:2818-2826.

10. Romero, M., J. G. Douglas, and U. Hopfer. 1990. P-450 monooxygenase in early S1 primary cultures. Kidney Int. 37:162A. (Abstr.)

11. Schwartzman, M., M. A. Carroll, N. G. Ibraham, N. R. Ferreri, E. SonguMize, and J. C. McGiff. 1985. Renal arachidonic acid metabolism: the third pathway. Hypertension (Dallas). 7(Suppl. I):I-136-I-144.

12. Smith, W. L. and G. T. Bell. 1978. Immunohistochemical localization of the prostaglandin-forming cyclooxygenase in renal cortex. Am. J. Physiol. 235:F451-F4.

13. Imbert-Teboul, M., S. Siaume, and F. Morel. 1986. Sites of prostaglandin $\mathrm{E}_{2}\left(\mathrm{PGE}_{2}\right)$ synthesis along the rabbit nephron. Mol. Cell. Endocrinol. 45:1-10.

14. Hassid, A., F. Sun, and M. D. Dunn. 1982. Lipoxygenase activity in rat kidney glomeruli, glomerular epithelia cells and cortical tubules. J. Biol. Chem. 257:10294-10299.

15. Snyder, G., F. Lattanzio, P. Yadogiri, J. R. Falck, and J. Capdevila. 1986 5,6-Epoxyeicosatrienoic acid mobilizes $\mathrm{Ca}^{2+}$ in anterior pituitary cells. Biochem. Biophys. Res. Commun. 139:1188-1194.

16. Snowdowne, K. W., L. Rosenoer, E. Yu, and J. R. Cashman. 1989. Eicosanoids evoke the release of amylase and increase cytoplasmic calcium in rat parotid cells. Biochem. Biophys. Res. Commun. 161:379-384.

17. Cashman, J. R., D. Hanks, and R. I. Weiner. 1987. Epoxy derivatives of arachidonic acid are potent stimulators of prolactin secretion. Neuroendocrinology. 46:246-251.

18. Negro-Vilar, A., A. D. Snyder, J. R. Falck, S. Manna, N. Chacos, and J. Capdevila. 1985. Involvement of eicosanoids in release of oxytocin and vasopressin from the neural lobe of the rat pituitary. Endocrinology. 116:2663-2668.

19. Falck, J. R., S. Mann, J. Moltz, N. Chacos, and J. Capdevila. 1983. Epoxyeicosatrienoic acids stimulate glucagon and insulin release from isolated rat pancreatic islets. Biochem. Biophys. Res. Commun. 114:743-749.
20. Capdevila, J., N. Chacos, J. R. Falck, S. Manna, A. Negro-Vilar, and S. Ojeda. 1983. Novel hypothalamic arachidonate products stimulate somatostatin release from the median eminence. Endocrinology. 113:421-423.

21. Snyder, G. D., J. Capdevila, N. Chacos, J. Manna, and J. R. Falck. 1983 Action of luteinizing hormone-releasing hormone: involvement of novel arachidonic acid metabolites. Proc. Natl. Acad. Sci. USA. 80:3504-3507.

22. Mene, P., G. R. Dubyak, A. Scarpa, and M. R. Dunn. 1987. Stimulation of cytololic free calcium and inositol phosphates by prostaglandins in cultured rat mesangial cells. Biochem. Biophys. Res. Commun. 142:579-586.

23. O'Flaherty, J. T., and J. Nishihira. 1987. 5-Hydroxyeicosatetraenoate promotes $\mathrm{Ca}^{2+}$ and protein kinase $\mathrm{C}$ mobilization in neutrophils. Biochem. Biophys. Res. Commun. 148:575-581.

24. O'Flaherty, J. T., D. Jacobson, and J. Redman. 1988. Mechanism involved in the mobilization of neutrophil calcium by 5 -hydroxyeicosatetraenoate. J. Immunol. 140:4323-4328.

25. Naccache, P. H., P. Borgeat, and E. J. Goetzl. 1981. Mono- and dihydroxyeicosatetraenoic acids alter calcium homeostasis in rabbit neutrophils. $J$. Clin. Invest. 67:1584-1587.

26. Fukuo, K., S. Morimoto, E. Koh, S. Yukawa, H. Tsuchiya, S. Imanaka, H. Yamamato, T. Onishi, and Y. Kumahara. 1986. Effects of prostaglandins on the cytosolic free calcium concentration in vascular smooth muscle cells. Biochem. Biophys. Res. Commun. 136:247-252.

27. Koop, D. R., R. M. Laethem, A. L. Goldner, and J. G. Douglas. 1991. Isolated rabbit renal epithelium cells for the study of cytochrome $\mathbf{P 4 5 0}$ expression and metabolism. Methods Enzymol. In press.

28. Chung, S. D., N. Alavi, D. Livingston, S. Hiller, and M. Taub. 1982. Characterization of primary rabbit kidney cultures that express proximal tubule functions in a hormonally defined medium. J. Cell Biol. 95:118-126.

29. Romero, M. F., U. Hopfer, Z. T. Madhun, J. Zhou, and J. G. Douglas. 1991. Angiotensin II mediated signaling mechanisms and electroplye transport in the rabbit proximal slides. Renal Physiol. Biochem. 14:199-207.

30. Douglas, J. G., M. Romero, and U. Hopfer. 1990. Signaling mechanisms coupled to the angiotensin receptor of proximal tubular epithelium. Kidney Int. 38(Suppl. 30):S43-S47.

31. Grynkiewicz, A., M. Poenie, and R. Y. Tsien. 1985. A new generation of $\mathrm{Ca}^{2+}$ indicators with greatly improved fluorescent properties. J. Biol. Chem. 260:3440-3450.

32. Fabiato, A. 1988. Computer programs for calculating total from specified free or free from specified total ionic concentrations in aqueous solutions containing multiple metals and ligands. Methods Enzymol. 157:378-417.

33. Griffin, H. D., and J. N. Hawthorne. 1978. Calcium-activated hydrolysis of phosphatidyl-myo-inositol 4-phosphate and phosphatidyl-myo-inositol 4,5bisphosphate in guinea-pig synaptosomes. Biochem. J. 176:541-552.

34. Dominguez, J. H., K. V. Snowdowne, C. C. Freudenrich, T. Brown, and A. B. Borle. 1987. Intracellular messenger for action of angiotensin II on fluid transport in rabbit proximal tubule. Am. J. Physiol. (Renal Fluid Electrolyte Physiol.). 252:F423-F428.

35. Norman, J., B. Badie-Dezfooly, E. P. Nord, I. Kurtz, J. Schlosser, A Chaudhari, and L. G. Fine. 1987. EGF-induced mitogenesis in proximal tubular cells: potentiation by angiotensin II. Am. J. Physiol. (Renal Fluid Electrolyte Physiol.). 253:F229-F309.

36. Harris, P. J., and J. A. Young. 1977. Dose-dependent stimulation and inhibition of proximal tubular sodium reabsorption by angiotensin II in the rat kidney. Pfluegers Arch. Eur. J. Physiol. 367:295-297.

37. Schuster, V. L., J. P. Kokko, and H. R. Jacobson. 1984. Angiotensin II directly stimulates sodium transport in rabbit proximal convoluted tubules. $J$. Clin. Invest. 73:507-515.

38. Romero, M. F., Z. Madhun, U. Hopfer, and J. G. Douglas. 1990. An epoxygenase metabolite of arachidonic acid, 5,6-epoxy-eicosatrienoic acid mediates angiotensin-induced natriuresis in proximal tubular epithelium. Adv. Prostaglandin Thromboxane Leukotriene Res. 21:205-208.

39. Sakhrani, L. M., N. Tessitore, and S. G. Massry. 1985. Effect of calcium on transport characteristics of cultured proximal renal cells. Am. J. Physiol. (Renal Fluid Electrolyte Physiol.). 249:F346-F355.

40. Wang, T., and Y. L. Chan. 1991. The role of phosphoinositide turnover in mediating the biphasic effect of angiotensin II on renal tubular transport. $J$. Pharmacol. Exp. Ther. 256:309-317.

41. Weiman, E. J., W. P. Dubinsky, K. Fisher, D. Styrlock, Q. Dihn, L. Chang, and S. Shenolikar. 1988. Regulation of reconstituted renal $\mathrm{Na}^{+} / \mathrm{H}^{+}$exchanger by calcium dependent protein kinases. J. Membr. Biol. 103:237-244.

42. Robison, G. A., R. W. Butcher, and E. W. Sutherland. 1971. Cyclic AMP. Academic Press, Inc., New York.

43. Ordway, R. W., J. V. Walsh, and J. J. Singer. 1989. Arachidonic acid and other fatty acids directly activate potassium channels in smooth muscle cells. Science (Wash. DC). 244:1176-1179.

44. Madhun, Z., U. Hopfer, and J. G. Douglas. 1991. Arachidonic acid and other fatty acids mobilize calcium in rabbit proximal tubular epithelial cells. Clin. Res. 39:186a. (Abstr.) 